\title{
The Place of Quality Market Research in Real Estate Investment Decisions
}

\author{
Nworah, Joseph .C. \\ Department of Estate Management \\ University of Nigeria, Nsukka, Nigeria
}

\begin{abstract}
There has been overwhelming recognition of the contributions of quality Market Research to real Estate Investment decisions in recent times. This study assessed the place of quality Market Research in global real Estate Investment decisions and exhaustively discussed the importance of quality Market Research in Real Estate Investment decisions. The study showed that quality Market Research is imperative for any meaningful investment decisions. The importance attached to quality Market Research for Real Estate Investment purposes was further assessed by the extent to which potential investors and investment analysts comply with set standards in their pre-investment and developmental appraisals with regard to the market Research in key determinants/ elements of Real Estate Investment. The study shows that $98.8 \%$ of the respondents actually carry out market research prior to investment decisions signifying the quantum of importance attached to Market Research for Real Estate Investment. The study further showed that $83 \%$ of the respondents strongly agree that quality Market Research is relevance in embarking on Real Estate Investment and impacts positively in their investment decisions. The study further indicated a mean score of 3.0 and above on the level and extent of Market Research conducted by potential investors .which by implication shows the relevance and importance attached to quality Market Research in Real Estate Investment decisions. The study further recommended that a standard Market Research Manual or standard pre-investment study template stipulating the data content of Market Research should be provided by relevant authorities or concerned professionals to ensure standardization .
\end{abstract}

Keywords: Real Estate development, Real Estate Investment, Market Research, Investment decision, pre-investment studies.

\section{INTRODUCTION}

There have been conflicting reports on the origin of market research in business but appreciable number of records indicate that earlier application and use of Market Research could be traced to its use by Newspapers in the early Nineteenth Century to predict election results and was further used for the estimation of the marketability of agricultural products by the United States Agricultural Machinery Manufacturers (Sharma, 1999).

However, despite the conflicting records of the origin of market research and its application in business, the use, role, importance and contributions of market research to business development generally, and in particular, real estate development and investment are enormous, crucial and cannot be over-emphasized (Ge\&Hartfield, 2006). The work of Hartfield highlighted the relevance of market research and further concluded that the place of market research and the contributions of quality market research to real estate investment will be better recognized and appreciated if the quality of data provided for pre-investment studies is reliable and guarantees valid information. This position corroborates the earlier work of (Umeh, 1977) which posited that the quality of preinvestment appraisal depends to a great extent on the efficiency, qualification and experience of the market research analyst.Furthermore, the extent of the role or contributions expected from market research in real estate investment depends hugely on the skill and competence of the market research professional carrying out the pre-investment research, the quality of data presentation, analysis and application in investment decisions (Nworah, 2019).

This study evaluated the role, importance or contributions of market research to real estate investment decisions by invariably looking at the quality of professionals assigned to do the job based on their experience, area of specialization, professional qualification, experience, the extent of application of market research in real estate investment decision as well as evaluation of the level and depth of research conducted for project development and investment. It is envisaged that the outcome of the above analysis will invariably indicate the importance attached to market research by real estate development and investment companies and stakeholders prior to taking investment decisions. 


\section{LITERATURE REVIEW}

Real Estate Investment decisions are hinged on quality Market Research for effective projections (Nworah, 2019). There have been several efforts by several Authors on Market Research for Real Estate Investment with some of the works concentrating on the short comings of market research.(Otegbulu, 2011) in his work concluded that investment decisions could be affected by inadequacies in market data collection, poor data analysis and appraisers' attitude. The importance of Market Research was however highlighted further by some of the renowned Authors in Real Estate Market Research as (Gambo et al, 2012) concluded that there is poor application of market research among Nigeria Estate Surveyors and Valuers and further stated that there is negligence and gross incompetence on the part of Nigerian Estate Surveyors and Valuers in carrying out market research. Miles et al (2007) in highlighting the importance and contributions of market research in real estate development and investment concluded that market research functions as the backbone of the real estate development process by providing the critical input for the investment analysis. That study further posited that real estate market research is inevitable because it forms the basis for the underlining assumption made about the value of a real estate development and investment since data for cash flow projections are based on intensive market research process.

Again, Ogunba(2011) in his study on the place of real estate market research concluded that the determination of the depth and condition of a particular real estate market and its ability to support a particular development and investment is based on market analysis as designed. Similarly, Mckenzie\& Betts (2011) posited that real estate market research is imperative prior to undertaking a real estate project and taking investment decisions because an in-depth market analysis is inevitable in estimating the adequacy of buyer demand for the proposed project. The study concluded that a Real Estate Market Research helps in avoiding bad projects when it is properly used by qualified development team in the design of a project and for marketing of the investment.

Ge\&Hartfield (2006) emphasized the role of market research in making quality data available which invariably plays a vital role in providing reliable and valid information which enhances property market performance and further stated that market research is the major anchor between the property investor's product concept and the end users taste and preferences. Simon \& Harris (1995) is of the opinion that market research helps to interpret consumer behavior and translates the perspective of key customers into actionable marketing strategies and clearly opined that market research plays pivotal role in determining the balance of scale between available building stock and profile of demand for building. In buttressing the importance of market research and the role it plays in real estate development and investment decisions, (Harris, 2019) averred that market research provides valuable clues to the likely trends in premises requirements while Tilford (2009) opined that the fundamental purpose of market research is to inform the developer or investor proposing to undertake a new venture about the applicable market conditions as they relate to the proposed project or investment.

\section{CONCEPT OF INVESTMENT}

The general understanding of Investment is anchored on the premise of putting down money or setting money aside for commencement or expansion of asset purchase or project or for the purpose of generation or to put it succinctly, for future returns or capital appreciation bearing in mind the possibility of certain degree of risk.

There are several theories and definitions of investment by notable authors. Mickenzie et al (2011) refers to investment as the giving up of present consumption in exchange for future benefits. It represents present sacrifice of something for the prospect of later benefits. Investment could therefore be expressed as a commitment of a given sum of money or the giving up of a capital sum now in exchange for benefit to be received in future, such benefits could come in form of income flows and/or capital gains and usually expressed as $\mathrm{P}=\mathrm{P}(\mathrm{B})$, where $\mathrm{P}=$ Price or value sacrificed; $\mathrm{F}=$ the functional relationship; and $\mathrm{B}=$ benefits receivable over time (Scot et al, 2001).

Consequently, real estate investment - the tying down of a capital for expected income flows or returns or capital appreciationrequires efficient and quality market research. This is practically so because real estate investment comes with attendant risks and therefore requires sufficient data for the analysis of the expected or future cash flows emanating from the commitment of initial capital. The nature of real estate makes it imperative that investment in the sector requires thoughtful or rational commitment of resources to ensure reasonable expectation of definite returns or benefits and such, investment also requires thorough analysis of all relevant variables and parameters before commitment of resources is made.

Esty (2002) concluded that sufficient market research is inevitable for any activity in which money is put down for the purpose of making profit or for future return because of the risk involvement. It then follows that any prudent investor in real estate would usually carry out diligent market research because investment decisions in real estate is made upon the estimation of expected returns which is characterized by several risks. Esty (2002) further highlighted the need for appropriate market research when he posited that risk/return analysis is a fundamental focus of real estate investment and therefore factors likely to affect the possible outcome of the investment will have to be investigated through proper market research and data analysis.

\section{MARKET RESEARCH AND ITS PLACE IN REAL ESTATE INVESTMENT DECISIONS}




\section{Market Research \\ Several authorities have defined Market Research in diverse ways. The most consistent of these definitions is by the British Institute of Management (1962) which defined Market Research as \\ "the systematic gathering, recording and analyzing of all facts relating to the transfer and sales of goods and services from Producer to Consumer”.}

Similarly, the Apraisal Institute defined Market Research as:

"the identification and study of the Market for a particular economic good or services"

While the DJS Research (2012) defined Market Research as:

\section{"a systematic, objective collection and analysis of data about a particular target market, competition, and/or environment”.}

Geltner and Miller (2014) was emphatic in their description of Real Estate Market Research and analysis when they described same as the various practical and analytical tools and procedures that real estate investors apply in their decision making process connected to real estate while Button (2012) describes market research as a process that identifies and studies the demand for and supply of real estate, classifying prospective users and competitions; defining the markets in terms of location and trade areas; providing vital, information to minimize risk and maximize opportunity; and examining market potential and competitiveness of proposed projects and summarized his opinion as the art and science of crafting a compelling story about the subject property.

Summarily and as could also be deduced from the various definitions, it is the opinion of this Author that market research entails collection of data and analysis of same aimed at investigations on the current and future postulations of real estate demand, supply, competition and competitive edge, user/consumer behavior, location and risk analysis; market entry potentials and opportunities, which forms the guide for potential investment decisions (Nworah, 2019).

\section{The role/place/contributions of market research to real estate investment decisions}

Real Estate Investors have consistently acknowledged the invaluable contributions of market research in real estate investment decisions. Real Estate Research has therefore taken prominent position and played very active role in determining the direction of Real Estate Investment decisions.

Umeh (1977) \&Hartfield (2006) in separate works acknowledged the increasing recognition accorded quality market research by real estate developers and investors and highlighted the vital roles played by market research in providing reliable and valid information for potential real estate investment decisions. Umeh further exhaustively discussed the relationship between the quality of market research and the quality of investment appraisals which he opined depends heavily on the qualification, experience, competence and skill with which the researcher identifies, assembles, process, and presents relevant data, facts, and figures towards solving the research problem. Nworah (2019) in his further work on the subject concluded that the quality of market research affects the outcome of investment decisions, marketability and profitability of the investment. It would therefore be said that market research plays prominent role in the determination of the outcome of investment decisions as well as in the determination of the marketability and profitability of a particular real estate investment. A quality real estate market research helps to produce and analyze relevant data on real estate key performance indicators such as yield, rental growth, total returns, market stock, and sales. Prices which in turn helps to produce valuation and cash flow records for real estate investors for efficient evaluation of real estate performance (La Salle, 2008).

Again, quality real estate research takes prominent place as a result of its contributions in encouraging cross-border real estate capital flows for real estate investment flows especially in developing countries of Africa (Nworah, 2019).This is so because globalization of real estate investment is usually supported by standard market research with documented analysis of certain indices or market indicators such as rental growth, capital growth, prices, rental indices, yield, total returns which can only be obtained by market research (La Salle , 2008). Detailed market research guides the potential investor in the process of identifying and studying the demand for and supply of real estate market; identifying potential or prospective users and analyzing competition; defining markets in terms of location and trade areas; providing vital information to minimize market potentials and competitiveness of proposed projects (Button, 2012). It is also noteworthy according to Miles et al (2007) that real estate market research functions as the backbone of the real estate development process since it provides the critical inputs for investment analysis and forms the basis for the assumptions made on the value of a real estate development as well as aids in defending cash flow projections by making relevant data available. The separate works of Ogunba (2011) and Mackenzie \& Betts (2011) also demonstrated the inevitable roles and contributions of real the estate market research when they separately concluded that real estate market research helps to determine the depth and condition of a particular real estate market and its ability to support a 
particular development; helps to estimate the adequacy of buyer-demand for the proposed project; and helps avoid bad projects when used by the development team to design the project and for marketing. Furthermore, it is agreed by real estate investment stakeholders that quality data realized from real estate market research plays vital role in providing reliable and valid information for property market performance and consequently provides the requisite linkage between property investor's product concept and end users tastes and preferences as well as data for interpretation of consumer behavior (Ge\&Hartfield, 2006).

Another fundamental contribution of market research in real estate development and investment decisions sterms from the submissions of Harris (2019) that marked research provides valuable clues to the likely trends in premises requirements and that the fundamental purpose of market research is to inform a developer considering a new venture about the applicable market conditions and their relationship with proposed projects. Market research is also a veritable tool in achieving product positioning so that a new product brought into the market can compete effectively and complement existing ones instead of merely duplicating them. Real Estate Market Research is a notable consequential part of the real estate development planning process and used to avert economic waste due to bad projects in property investment projects. It is fundamental to economic decision-making and its relevance is further argued by Greer \& Kolbe (2003) who argued that market research is an essential element in rational decisionmaking noting that it helps in assessing the quality of existing operations and evaluation of proposed changes for optimum profitability.

In summary, quality, efficient, objective and acceptable real estate market research provides unbiased and accurate information reflecting the true state of affairs and capable of being used for real estate investment analysis and decisions in key areas of demand estimation and supply analysis, customer satisfaction /consumer behavior, buyer-seller decision making, sales forecasting, price elasticity testing, valuations and cash flow analysis.

\section{METHODOLOGY}

This study carefully selected Lagos Metropolis- Lagos - Nigeria as the study area because it is the most active city for real estate business in Nigeria with a robust economic base, property development activity and investment potential required for a study of this nature. The study adopted the survey design/descriptive design to describe each of the variables necessary for the study. The study population comprises respondents who carry out market research for real estate investment in Lagos metropolis. Simple random sampling technique was applied which ensured that every member of the sub-set within the targeted population has equal opportunity of being selected. Data for this study was obtained from primary and secondary sources. Primary data was collected through structured questionnaire/interview to respondents who carry out market research for real estate development, real estate investors and stakeholders in the study area. Secondary data was sourced from textbooks, journals, published papers and articles. For this study, the data collected was analyzed using simple descriptive tools such as frequency distribution tables, charts, percentage, mean score, depending on statistics of interest and data behavior. The validity and reliability of the research instrument were further confirmed by ensuring that appropriate questions were structured and discussed with experts to seek their views. The criticisms, comments and reviews were used to improve and modify the content of the questionnaire. Additionally, a pilot exercise was carried out on the respondents by administering a few questionnaires on a few respondents to ensure that all the questions were understood.

\section{RESULTS AND DISCUSSIONS}

\section{Characteristics of the respondents}

Figure 1 represents expression of the characteristics of the respondents with regard to academic qualification. The essence of obtaining information on the respondents'academic qualification is to establish that those entrusted with the responsibility have the requisite academic back ground. The academic level attained by these respondents reflects the importance attached to market research report by the firms or investors engaging the respondents. Majority (67\%) of the respondents engaged in market research on behalf of the firms or investors possesses B.A/BSc/B.Tech. $20.5 \%$ holds HND Certificate while $11.4 \%$ and $1 \%$ hold up to M.Sc and PhD levels respectively. This shows that all the respondents are graduates of various higher institutions and some in fact have higher degrees (M.Sc, PhD) and impliedly, real estate market research end users and stakeholders place high importance on the role of market research for their investment decisions by engaging high level qualified researchers for their market research report which will guide them in making decisions. 


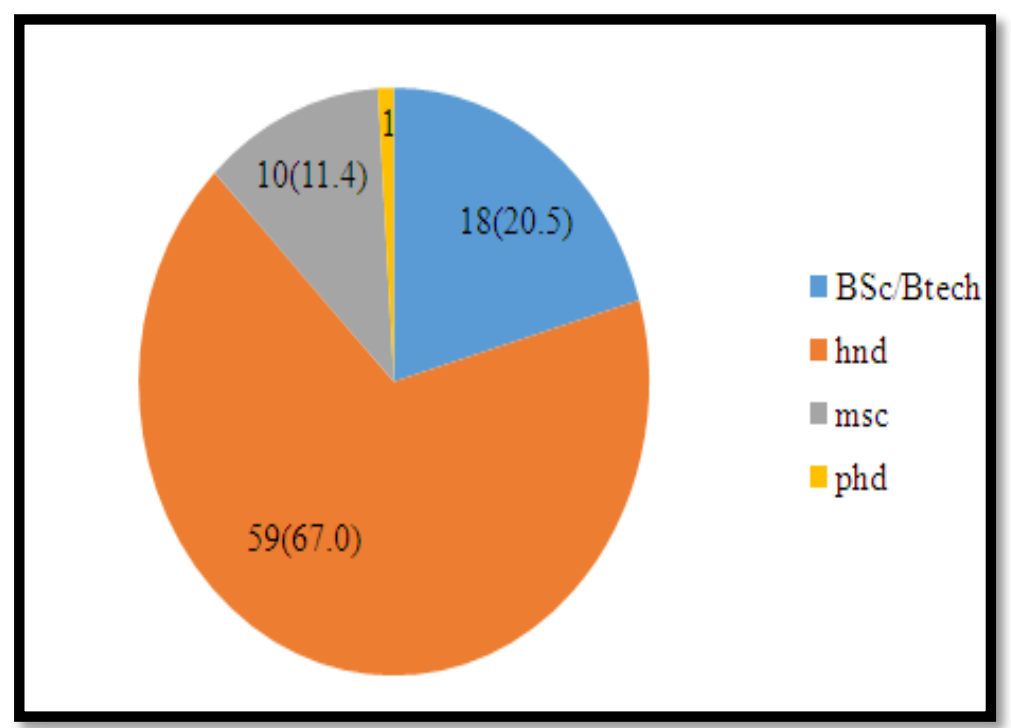

Figure 1: Academic qualification of the respondents.

Source: Author's field survey 2018.

Table 1: Respondents' characteristics

\begin{tabular}{|c|c|c|}
\hline & Frequency & Percentage \\
\hline Category of respondents & & 93.3 \\
\hline Estate surveyors & 84 & 6.7 \\
\hline Estate surveyors/Developers & 6 & 100 \\
\hline Total & 90 & 22.9 \\
\hline Position in firm & 19 & 43.4 \\
\hline Managing partner & 36 & 33.7 \\
\hline Branch manager & 28 & 100 \\
\hline Senior surveyor & 83 & 50.0 \\
\hline Total & & 6.1 \\
\hline Professional affiliation & 41 & 43.9 \\
\hline ANIVS/RSV & 5 & 100 \\
\hline FNIVS & 36 & 36.8 \\
\hline Others & 82 & 27.6 \\
\hline Total & & 18.4 \\
\hline Working experience & 32 & 10.3 \\
\hline $1-5$ years & 24 & 6.9 \\
\hline $6-10$ years & 16 & 100.0 \\
\hline $11-15$ years & 9 & \\
\hline $16-20$ years & 6 & \\
\hline 21 above & 87 & \\
\hline Total & & \\
\hline
\end{tabular}

Source: Author's field Survey 2018

Table 1 shows that majority (93.3\%) of the respondents are estate surveyors and Valuers grounded in real estate matters while (6.7\%) are not only estate surveyors and Valuers but are additionally involved in real estate development. Again $43.4 \%$ of the respondents were head of operations/branch managers of their respective organizations, 33.7\% were senior estate surveyors and Valuers/Directors and the remaining 22.9\% were managing partners/managing directors/CEO's. This also implies that real estate market research end users/investors value market research by engaging the top most members of their firms - the M.D/CEO and level of directors in their market research report.

Also, the table shows that $50 \%$ of the respondents hold professional qualifications of MBA/ANIVS/RSV; $43.9 \%$ were research executives/officers; while $6.1 \%$ were FNIVS/ICAN (FCA). This means that most of the respondents involved in real estate market research are professional associates or fellows of their professional bodies indicating the level of prominence accorded market research in investment decisions. 
The table also indicates that $36.8 \%$ of the respondents have been working in area of real estate market research for $1-5$ years; $27.6 \%$ have working experience ranging from 6- 10 years; while respondents who have been working on market research for 11 15 years account for $18.4 \%$. About $10.3 \%$ have working experience of $16-20$ years while $6.9 \%$ have been carrying out market research for 21 years and above.Furthermore, analysis of the respondents indicates that $63.6 \%$ of the respondents have been carrying out real estate market research for period ranging from $6-21$ years. As a matter of fact, majority of the firms involved in real estate market research have actually been in the business for over 10years (11-20years) and a further analysis shows that $14.6 \%$ of the firms have been in real estate research business for over 20years $(21$ - 30years). This implies that majority of the firms/respondents were in a good position to attend to the research questions and that the data obtained from the research questions could be well relied up in drawing research conclusions on the role, importance and contributions of real estate market research. The chart below expresses the respondents' years in real estate market operations.

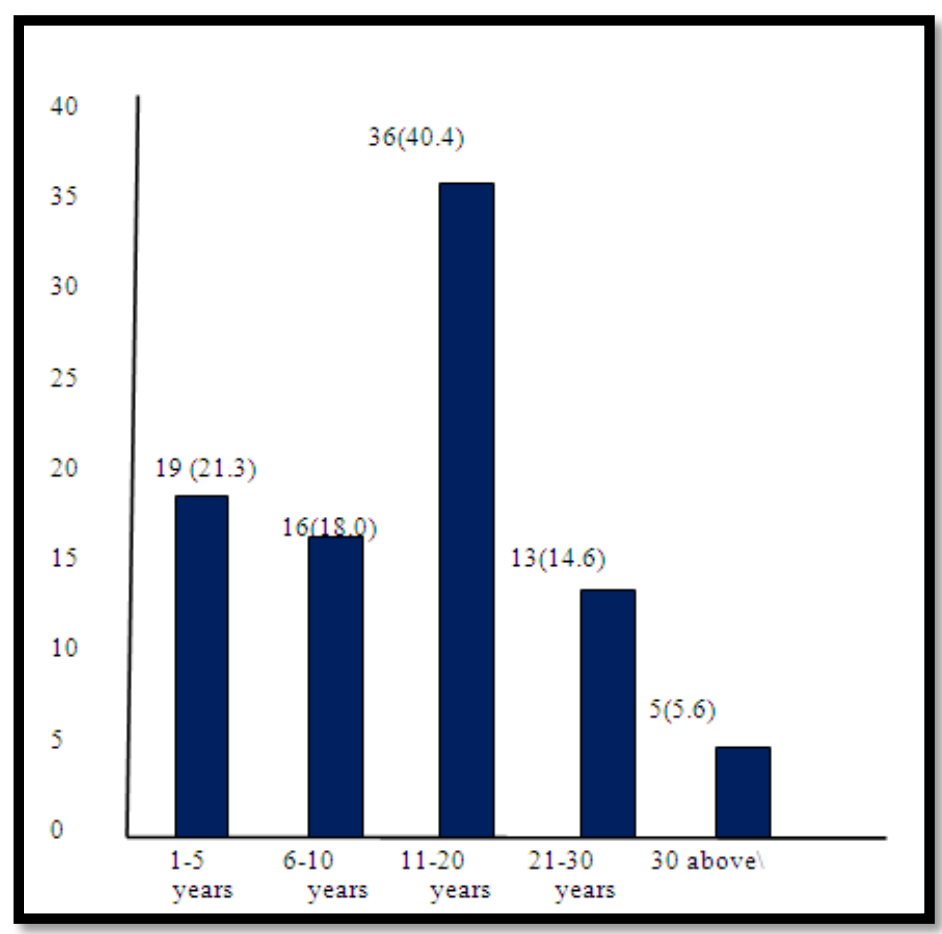

Figure 2: Number of Years in Operation

Source: Author's field Survey 2018

Table2: Firms' Experience in Real Estate Market Research/Investment Appraisals.

\begin{tabular}{|c|c|c|}
\hline & Frequency & Percentage \\
\hline $\begin{array}{c}\text { Have Your Firm Carried Out Feasibility and } \\
\text { Viability Study }\end{array}$ & & 93.2 \\
\hline Yes & 62 & 6.8 \\
\hline No & 88 & 100.0 \\
\hline Total & & 22.9 \\
\hline $\begin{array}{c}\text { How often have you carried out feasibility And } \\
\text { viability }\end{array}$ & 24 & 43.4 \\
\hline 1 & 25 & 33.7 \\
\hline 2 & 7 & 16.5 \\
\hline 3 & 13 & 12.7 \\
\hline 4 & 10 & 100 \\
\hline 5 above & 79 & \\
\hline Total & & \\
\hline
\end{tabular}

Source: Author's field Survey 2018

Table 2 above expresses the firms/respondents working experience in real estate market research/investment appraisals. From the data collected and analyzed, $93.2 \%$ of the respondents have carried out real estate market research and actually applied same for real estate investment analysis. However, the frequency of the exercise shows that despite the importance of market research for real estate investment decisions, some investors are yet to take full advantage of the benefits of market research and some firms are still not conversant with the contributions of market research in real estate investment decisions. The table shows that about 
$62 \%$ of the respondents have carried out only between 1-2 market research/investment appraisals since they started operations which by implication revealed that real estate investors have not fully taken advantage of market research in their investment decision or have not fully appreciated the need for or relevance of formal market research/investment appraisal or simply have not fully recognized the critical position of real estate market research in investment decision which is typical of developing economies. This position tarries with the conclusions of Mckenzie\& Betts (2011); Scot et al (2001), and La Salle, (2008).

Table 3: Application of Market Research by Real Estate Investors/Investment Appraisers in Investment Decisions.

\begin{tabular}{|c|c|c|}
\hline & Frequency & Percentage \\
\hline Do you conduct market research & & \\
\hline Yes & 83 & 98.8 \\
\hline No & 1 & 1.2 \\
\hline Total & 84 & 100 \\
\hline Is market research relevant in embarking on real estate investment & 73 & 83.0 \\
\hline Strongly agreed & 15 & 17 \\
\hline agreed & 88 & 100.0 \\
\hline Total & & \\
\hline
\end{tabular}

\section{Source: Author's field Survey 2018.}

Table 3 above shows the summary of findings with regard to the application and relevance of market research in investment decisions. $98.8 \%$ of the firms indicated that they actually carry out real estate market research when embarking on real estate investment/investment decisions. This totally agreeswith the conclusions of Gambo et al (2012) which posited that almost all the Estate Surveyors and Valuers in Lagos Island, Nigeria, admitted using market research for their investment appraisals.

Table 4: Evaluation of key indicators/areas where market research aids investment decisions.

\begin{tabular}{|c|c|c|c|c|c|c|c|}
\hline & Poor & Average & Good & V.Good & Excellent & $\begin{array}{l}\text { Mean } \\
\text { Score }\end{array}$ & Ranking \\
\hline $\begin{array}{l}\text { Trend analysis of demand and } \\
\text { supply }\end{array}$ & $1(1.2)$ & $7(8.5)$ & $23(28.0)$ & $32(39.0)$ & $19(23.2)$ & 3.74 & $1^{\text {st }}$ \\
\hline $\begin{array}{c}\text { Locational structural attributes of } \\
\text { proposed development market }\end{array}$ & - & $9(10.8)$ & $24(28.9)$ & $33(39.8)$ & $17(20.5)$ & 3.69 & $2^{\text {nd }}$ \\
\hline $\begin{array}{c}\text { All feasibility and viability } \\
\text { Covering physical economic } \\
\text { Financial legal political cultural } \\
\text { indicators }\end{array}$ & $5(6.1)$ & $19(23.2)$ & $27(32.9)$ & $26(31.7)$ & $5(6.1)$ & 3.69 & $3^{\text {rd }}$ \\
\hline $\begin{array}{c}\text { Current and projected rental sales } \\
\text { value }\end{array}$ & $2(2.4\}$ & $9(10.8)$ & $21(25.3)$ & $34(41.0)$ & $17(20.5)$ & 3.66 & $4^{\text {th }}$ \\
\hline Current level/sources of demand & $1(1.2)$ & $5(6.2)$ & $29(35.8$ & $35(43.2)$ & 11(13.6) & $3.61)$ & $5^{\text {th }}$ \\
\hline Customers tastes and Preferences & $1(1.2)$ & $7(8.6)$ & $30(37.0)$ & $30(37.0)$ & $13(16.0)$ & 3.58 & $6^{\text {th }}$ \\
\hline $\begin{array}{l}\text { Forecast of future demands and } \\
\text { supply }\end{array}$ & - & $10(12.0)$ & $34(41.0)$ & $25(30.1)$ & $14(16.9)$ & 3.52 & $7^{\text {th }}$ \\
\hline Existing supply or competition & $2(2.4)$ & $10(12.2)$ & $7(32.9)$ & $36(43.9)$ & $7(8.5)$ & 3.44 & $8^{\text {th }}$ \\
\hline Stage of the property cycle & _ & $7(9.0)$ & $42(53.8)$ & 21(26.9) & $8(10.3)$ & 3.38 & $9^{\text {th }}$ \\
\hline State of the economy & $5(6.3)$ & $16(20.0)$ & $29(36.3)$ & $22(27.5)$ & $8(10.0)$ & 3.15 & $10^{\text {th }}$ \\
\hline Associated risks & - & $27(30.0)$ & $26(32.1)$ & $20(24.7)$ & $8(9.9)$ & 3.11 & $11^{\text {th }}$ \\
\hline $\begin{array}{c}\text { Demographic data of target market } \\
\text { such as age income marital status } \\
\text { etc }\end{array}$ & $5(6.1)$ & $19(23.2)$ & $27(32.9)$ & $26(31.7)$ & $5(6.1)$ & 3.09 & $12^{\text {th }}$ \\
\hline
\end{tabular}

Source: Author's field Survey 2018. 
Table 4 above shows the analysis and evaluation of key indicators/areas where real estate market research plays prominent roles in investment decisions. The table reveals a mean score of 3.0 and above on the role/relevance of market research for real estate investment decisions. Impliedly, real estate market research plays key role in analyzing of critical elements or factors affecting real estate investment decisions.

\section{SUMMARY OF FINDINGS, CONCLUSION AND RECOMMENDATIONS}

\section{Summary of Findings}

1. The result of the analysis from the administered questionnaire established that real estate investors also invest in market research by engaging highly qualified and experienced professionals to carry out real estate market research in the course of embarking on real estate development and investment which is an indication of the level of importance attached to market research by end users and investors in taking investment decisions.

2. The study also established that real estate investors depend heavily on the outcome of market research in key indicators/factors or elements such as trend analysis of demand and supply with mean score of 3.74 in the evaluation of the importance of market research on these factors and a mean score of 3.0 and above on the level of importance of the various factors considered by investment analyst and appraisers.

3. Also, the analysis from the study indicate that most of the research firms have only carried out between $1-2$ market research assignment since the commencement of operations by the firm leading to the conclusion that unlike what is obtainable in developed economies, developing nations have not given market research its critical position in investment decisions and real estate investors in the study area are yet to fully take advantage the several contributions of market research by understanding the need and relevance of formal market research for investment appraisals and decisions.

\section{CONCLUSION}

Based on the findings made from the analysis in this research, it is emphatically concluded that real estate investors in the study area engage professionally qualified and experienced market research analyst for their pre-development and preinvestment appraisals. The investors lay emphasis on market research for investment decision by holding market research in high esteem as very useful and relevant for investment decisions. However, there are still real estate market research firms that have not carried out market research for investment decisions while $62 \%$ of the respondents have carried out only $1-2$ market research for investment appraisals since commencement of their operation while some investors are yet to come to terms with the need or relevance of market research in investment decisions.

\section{RECOMMENDATIONS}

Having established that market research plays important roles in investment decisions, it is necessary to make market research compulsory part of real estate development and investment processes.

Government at different levels should also establish real estate research Institutes to provide guides, training, manuals etc for real estate investors. Various institutions of higher learning involved in courses leading to real estate qualifications should be encouraged to include market research as part of academic curriculum.

Establishment of real estate data bank is inevitable if market research for investment decision will take its prominent role in investment decisions and various professionals in the built-environment and other stakeholders in real estate investment business should make market research an important part of the continuous professional Programmes (CPD).

\section{REFERENCES}

1. Button, R. (2012). Market Research and Analysis: P.A Housing \& Land Development Conference, 2010 , pp 1 - 8.

2. Esty, .B. (2002). Return on Project Finance Investment, Evaluation and Managerial Implications. Journal of Applied Corporate Finance, spring.

3. Gambo, Y.I; Otegbulu, A.C; Omirin, M.M \&Osagie; J.U (2012). Market Research Applicability among Nigerian Estate Surveyors and Valuers in Project Appraisal. Mediterranean Journal of Social Sciences, 3,455 - 461.

4. Ge\&Hartfield, (2006). The Quality of Data and Data Availability for Property Research. School of the Built Environment, United Institute of Technology, New Zealand.

$\underline{1-2}$

5. Geltner, D \& Miller, .N. (2014): Commercial Real Estate Analysis and Investment (4 $4^{\text {th }}$ Edition): Centage Learning Inc.

6. Harris, .S. (2019). Conducting Market Research: Entrepreneur Media Inc.

7. Jones Lang La Salle (2008). Global Real Estate Transparency Index. 
8. Mackenzie, D \& Betts, R. (2001). Essentials of Real Estate Economics $\left(3^{\text {rd }}\right.$ Edition). Centage Learning. 2011. Business \& Economics.

9. Miles, M.E; Berens, C.I; Eppli, M.J \& Weiss, M.A, (2007). Real Estate Development Principles \& Process. Washington, Urban Land Institute, $13-14$.

10. Nworah, J.C (2019). Examination of the Role of Quality Market Research in Commercial Real Estate Investment In Developing Countries, Case Study of Lagos Nigeria. The International Journal of Humanities \& Social Studies. ISSN 2321 - 9203; Volume 7 Issue 5, May, 2019.

11. Ogunba, O.A (2011. How Adequate are Market Analysis in Pre-development Appraisal Reports? Journal of Contemporary Issues in Real Estate. 1(1), 23 - 28.

12. Otegbulu .A. (20110. The Impact of Jacuzzi Bathtubs on House Prices. Journal of Sustainable Development 4(3), 190 201.

13. Scot .A. Lauren E; Sergeant, J. (2001). Response Styles in Marketing Research. A Cross - National Investigation. Journal of Marketing Research, 38(2). 143 - 146.

14. Sharma, D.D (1999). Marketing Research: Principles Applications and Cases. $2^{\text {nd }}$ Edition.Sultan Chande\& Sons New Delhi.

15. Simon, G.S, \& Harris R.(1995). Property in a Global Risk Society: Towards Marketing Research. University of Newcastle, $1-32$.

16. Tilford, M.B (2009). Developing for Demand: An Analysis of Demand Segmentation Methods and Real Estate Development. M.Sc Thesis, Massachusetts Institute of Technology, $1-20$.

17. Umeh, J.A (1977). Feasibility and Viability Appraisal. Ibadan, Onibonoje, 1-29. 